\title{
Effect of Trichoderma spp on Plant Height of Local Rice Varieties in the Early Phase of Growth
}

\author{
Azwir Anhar ${ }^{1 *}$ Linda Advinda ${ }^{1}$ Dwi Hilda Putri ${ }^{1}$ V Atika ${ }^{1}$ S Amimi ${ }^{1}$ \\ ${ }^{I}$ Dept. of Biology, Faculty of Mathematics and Science (FMIPA), Universitas Negeri Padang, Padang, Indonesia \\ ${ }^{*}$ Corresponding author. Email: anharazwir@yahoo.com
}

\begin{abstract}
Shoots are important organs in plant growth, because the process of photosynthesis occurs in shoots, especially in plant leaves. Application Trichoderma as a bio fertilizer can increase the growth of shoots of various plants including superior varieties of rice plants. On the other hand, local rice varieties characterized by relatively slow growth Local varieties have not received sufficient attention of researchers to increase their growth. This has an unfavorable impact on preserving that variety in the field. This study aims to evaluate the response of local rice varieties to the application of Trichoderma spp in the seedbed and after transplanting. Two-factor factorial experiment was designed with a completely randomized design. Factor A consisted of 5 local rice varieties and Factor B consisted of 8 isolates and one control. Local variety was obtained from the West Sumtera region and the Trichoderma isolate came from the rhizosphere of lowland rice plants in Solok Regency and upland rice in West Pasaman. Application of Trichoderma spp is done by soaking the seeds with Trichoderma spp isolate. Response of plant height growth to isolates was observed when in the nursery at 2 weeks old and 2 weeks after transplanting. Data were processed by analysis of variance and Duncan's follow-up test at a significance of 5\%. The results showed that plant height is influenced by variety when in the seedbed, but was not affected by the application of Trichoderma spp. Although there was no interaction, plant height after transplanting was influenced by varieties and isolates. The best isolate to increase plant height is KRT with an average height of $86.1 \mathrm{~cm}$ compared to a control of only $81.5 \mathrm{~cm}$.
\end{abstract}

Keywords: Trichoderma, plant height, local rice, early phase, growth

\section{INTRODUCTION}

The green revolution that has been practiced in Indonesia since 1970 has been able to significantly increase domestic rice production. The application of intensification in the green revolution has succeeded in bringing Indonesia to achieve self-sufficiency in 1984 [1]. The use of new types of superior varieties, synthetic fertilizers and pesticides, and supported by the availability of sufficient irrigation water is a major component of the green revolution [2]. Many superior varieties were introduced as part of the Green Revolution to increase agricultural productivity. This genetically developed rice variety is centered at the International Rice Research Institute (IRRI) of the Philippines [3]. Although it was able to increase rice production and achieve self-sufficiency in rice in 1984, the green revolution also had various adverse effects human life system.

The Green Revolution is considered a technology that is not environmentally friendly [4]. Green revolution, has resulted in reduced agricultural biodiversity. The use of new superior varieties causes local variety to decrease. Over a period of 16 years, the area planted with local variety decreased from $42 \%$ to less than $20 \%$ [5]. In 1967 , paddy rice varieties in Indonesia were diverse, including over 7000 varieties. However, in 1965, the planting of local rice varieties was prohibited, resulting in the near extinction of local rice varieties [6]. Of the 94 local rice varieties in Solok Regency, West Sumatra only 24 varieties are still sustainable [7].

In recent years, fertilizer consumption increased exponentially throughout the world, causes serious environmental problems. Fertilization may affect the accumulation of heavy metals in soil and plant system. Plants absorb the fertilizers through the soil, they can enter the food chain. Thus, fertilization leads to water, soil and air pollution [8]. The use of synthetic pesticides in the green revolution resulted in poisoning in humans. Every year in developing countries there are 75,000 people suffering from insecticide poisoning and 14,000 of them died [9]. As a result of the negative impact of the use of pesticides, in 2010 in the commitment "Go Organic 2010" the government launched an organic agriculture program [10]. Organic farming is an agricultural system that can increase and maintain land productivity without using synthetic fertilizers and pesticides [11]. Organic farming is expected to be able to restore food production that is safe for consumption and high nutrition [10].

In general, the practice of organic cultivation still uses national superior varieties. In contrast, local rice varieties are still not a concern for researchers. In this case, local varieties have the advantage that is rarely found in superior rice varieties. The seeds are easy to obtain, not susceptible 
to disease pests, the taste of the rice is good and the price of rice is high [12]. On the contrary, the age of local varieties is longer so it requires large amounts of organic fertilizer [13]. With the high price of organic fertilizer, alternatives should be sought, namely the use of biofertilizer [14]. Bio-fertilizer is a material that contains microorganisms that work in plant rhizosphere, which is useful for increasing supply and nutrition and stimulating plant growth [15]. Biofertilizer is an alternative step to increase soil fertility, crop productivity and crop yields without causing harmful effects on the environment [16]. One group of microorganisms that can be used as biofertilizers is Plant Growt Promoting Fungi (PGPF) [17]. PGPF is able to spur growth because it is able to produce ZPT in the form of IAA, gibberellins and cytokines [18]. PGPF is able to produce substances needed to increase plant growth in the form of phytohormone, phosphate solvent, cellulose degradation and siderophore production [19]. Myroorganisms that include PGPF include Trichoderma, Fusarium, Penicillium and Phoma. The most widely used type is Trichoderma [20].

Organic farming which is widely practiced today is a rice intensification (SRI) system. One characteristic of SRI is removal of plants from the nursery at a younger age with plants that are still small and relatively weak. This stage is the most critical phase in the plant's life cycle. During this stage, plants have a high susceptibility to injury, disease, and environmental stress [21]. To overcome this, Trichoderma can be used to increase plant growth. The application of Trichoderma SL isolates was able to affect the percentage of germination, vigor index and the rate of germination of rice seed varieties MRQ74 [22].

Trichoderma application is able to provide a good response to germination and increase the height of upland rice seeds [23]. Trichoderma application does not always give positive results to plants. reported that five types of Trichoderma isolates did not affect the percentage of Sirandah Kuniang local rice variety seed germination [24]. The response of rice varieties to Trichoderma also showed different results, Trichoderma inoculation yielded a $26 \%$ higher yield in the superior variety Sukhadhan-3, while in the heirloom variety Tilkidhan gave $41 \%$ higher yields than control [25].

\section{MATERIALS AND METHODS}

The study was conducted at the screen house of the Department of Biology FMIPA UNP. This Factorial Experiment used a Completely Randomized Design with four replications. Factor $\mathrm{A}$ in the form of local rice consists of 5 varieties namely; AA 75, Batang Sungkai, Kuriak Kusuik, Mikonga and Saganggam. Factor B consisted of 8 Trichoderma isolates from the collection of Microbiology Laboratory of UNP Biology Department, namely KRT, RE, SB, SBT, SR, SRBA, SRU and TS.

Selection of seeds for treatment is done by soaking the seeds in a glass-filled becker Selection of seeds for treatment is done by soaking the seeds in a glass-filled becker. The submerged seeds are take out for use in research ${ }^{[26]}$. Surface sterilization of rice seeds is done by immersing in $70 \%$ ethanol for 30 seconds and then immersed in 5\% hipokhlorit for 30 seconds ${ }^{[22]}$ then the seeds are rinsed with sterile water. Fifty rice seeds were selected from each variety and then immersed in a flask containing $10^{7}$ trichoderma spore suspension $/ \mathrm{mL}$ for 30 minutes according to treatment. For negative control, seeds were only soaked in distilled water, while positive control was used Trichodermaa asperellum SL2. Treated seeds are placed in sterile petri dishes containing filter paper and given $10 \mathrm{ml}$ of sterile water ${ }^{[22]}$. Fifty rice seeds were selected from each variety and then immersed in a flask containing $10^{7}$ trichoderma spore suspension / $\mathrm{mL}$ for 30 second according to treatment. For negative control, seeds were only soaked in distilled water, while positive control was used Trichodermaa Asperellum SL2.

Plant media used is paddy soil taken from the suburbs of Padang. Seeds that have been treated with Trichoderma isolates are sown on a plastic tray filled with moist soil. 10-day-old rice seedlings, transferred one stem into a plastic pot containing $8 \mathrm{~kg}$ of soil. Observations were made on plant height 20 days after transplanting. Plant height is measured from ground level to the highest leaf tip. The data collected was processed using SPSS version 24.

\section{RESULT AND DISCUSSION}

The results showed that plant height growth was influenced by rice isolates and varieties. However, there was no interaction between isolate types and rice varieties. Rice plant height of 5 varieties ranged from 60.3 to 107.2 $\mathrm{cm}$ as shown in Table 1 and the effect of isolates on plant height is shown in Table 2.

Table 1. Plant height of five rice varieties $(\mathrm{cm})$

\begin{tabular}{ll}
\hline Varitas & Tinggi Tanaman \\
\hline Mikonga & $60,3^{\mathrm{a}}$ \\
AA 75 & $60,8^{\mathrm{a}}$ \\
Batang Sungkai & $87,7^{\mathrm{b}}$ \\
Kuriak Kusuik & $102,9^{\mathrm{c}}$ \\
Saganggam & $107,2^{\mathrm{d}}$
\end{tabular}

Number followed by the same letter not significant at the $5 \%$ level by DNMRT

Plant height of the five varieties of rice showed significant differences. Of the five varieties, Mikonga and AA 75 have no different height. In contrast, the varieties of Batang Sungkai, Kuriak Kusuik and Saganggam show different heights compared to each other or with the other two varieties. Plant height is an important agronomic trait of rice that directly affects the yield of this crop.The dwarf phenotype is beneficial for rice lodging, but if the plants are too short, it will lead to insufficient growth and 
ultimately affect the yield potential of rice [27]. The difference in genetic composition is one of the factors that causes the appearance of plant height varies [28]. The differences in plant height were determined more by genetic factors [29]. Elongation of internodes is under genetic control, and various factors are implicated in the process [30]. The gene that controls plant height in rice (Oryza sativa L.) is located on chromosome 1 (QTLph1). Sucrose phosphate synthase (SPS) is the targeted gene underlying QTLph1. Higher plant height was due to the high SPS activity [31]. Thus, each variety certainly contains unequal SPS, resulting in differences in plant height. Plant height influences the yield of grains such as rice (Oryza sativa). Gibberellic acid hormone (GA) regulates the process of development and role in plant height [32]. Thus, differences in variety result in different GA contents.

The genetic differences of the four varieties are also related to the origin of the varieties. The five varieties used in the study came from the districts of Pasaman, Solok, Bukittinggi and Payakumbuh. Of the five varieties tested, 4 of them had different plant height [33]. Of the four varieties of paddy that were tested, three varieties showed different plant height Of the four varieties of paddy that were tested, three varieties showed different plant height Of the four varieties of paddy that were tested, three varieties showed different plant height [34]. Ten local varieties tested also showed differences in height. Ten local varieties tested also showed differences in height Ten local varieties tested also showed differences in height [35]. Application GA on three varieties of rice japonica mediterania NRVC980385, Bomba and Dwarf - Bomba shows that Bomba variety is significantly higher than the other two varieties [36].

Table 2. Effect of Trichoderma isolates on Plant height (cm)

\begin{tabular}{lc}
\hline Isolates & Plant heigh \\
\hline Control & $81,5^{\mathrm{a}}$ \\
SRU & $81,7^{\mathrm{a}}$ \\
SR & $82,6^{\mathrm{ab}}$ \\
TS & $83,4^{\mathrm{ab}}$ \\
SRBA & $83,9^{\mathrm{ab}}$ \\
SBT & $84,4^{\mathrm{ab}}$ \\
SB & $84,7^{\mathrm{ab}}$ \\
RE & $85,8^{\mathrm{b}}$ \\
KRT & $86,1^{\mathrm{b}}$ \\
\hline
\end{tabular}

Number followed by the same letter not significant at the $5 \%$ level by DNMRT

Plant height is not only a decisive factor in plant architecture, but also an important agronomic trait that is directly linked to the harvest index and yield potential. The total number of elongated internodes and the length of each elongated internode determine plant height [37].The results showed that the response of plant height to Trichoderma isolates varied. The lowest plants were found in the control and highest in the KRT isolate (Table 2). Six isolates showed the same plant height response as control. In contrast, two isolates of RE and KRT showed different responses to controls but were not different from the other 5 isolates.

Trichoderma affects plant growth because of its ability to produce growth regulators. Evidences also suggest that Trichoderma produces plant growth regulatory material and phytohormone such as Indol acetic acid and their analogous [38]. Trichoderma spp. recently was suggested as a Plant Growth Promoting Fungi (PGPF) due to their ability to produce siderophores, phosphate-solubilizing enzymes, and phytohormones [19]. Secondary metabolites of Trichoderma spp., like arzianolide, may play a novel role in both plant growth regulation and defense responses [39]. Trichoderma spp. facilitates root colonization of their hosts by the production and regulation of hormonal signals [40]. Trichoderma strains that promote plant growth are found to produce the plant hormones auxin [41]. There is strong evidence for a role for microbe-produced indole acetic acid (IAA), although it is most likely that Trichoderma stimulates growth by influencing the balance of hormones such as IAA, gibberellic acid and ethylene [42].

The ability of Trichoderma spp. to produce phytohormones is the key factor in the increase in rice plant height [22]. Numerous data from mutants indicate that the pattern of internode elongation, which determines the height of rice plant, is regulated in two different ways: the genes controlling internode elongation either express in all internodes, allowing coordinated elongation of every internode, or the genes act only one or two internodes. The genes encoding gibberellic acid (GA) and brassinosteroid (BR) biosynthetic or signaling pathways have been identified using dwarf mutants of rice, and were found to act at all elongated internodes [37].

The difference in plant height response to Trichoderma isolates is thought to be related to the genetic characteristics of each isolate. The production of the various plant growth-promoting metabolites was a characteristic of individual strains, and not consistent within any species of Trichoderma. No single isolate was positive for all of the metabolites assessed [43]. Compared to control plants, levels of IAA were significantly higher in plants inoculated with the natural isolates T-10, T-17, and $\mathrm{T}-22$, whereas they were not altered in plants treated with isolates T-4 and T-7 [44]. Perbedaan respon tanaman bukan hanya disebabkan perbedaan kandungan IAA dari isolate. Cytokinins were reduced in shoots of plants colonized by isolates $\mathrm{T}-10$ and $\mathrm{T}-17$, and $\mathrm{T}-22$, which were the same strains that promoted plant growth. A significant increase in the auxin/cytokinins ratio (2 times higher) was found in shoot of plants inoculated with the growth-promoting isolates T-10, T-17 and T-22 [44] 


\section{CONCLUSION}

The result of the study prove that the hight of rice plant is influence by the rice variety and type of Trichoderma isolates. The highest rice plants were found in the Saganggam variety and the lowest in Mikonga. The lowest plants were found in the application of KRT isolates and the lowest in control. There was no interaction between the varietas of rice plants and the types of isolates.

\section{REFERENCES}

[1] Nurmalina, R. 2012. Swasembada Beras Yang Berkelanjutan Untuk Mendukung Ketahanan Pangan Nasional. Agrimedia Magazine, 17(2).

[2] Sumarno. 2006. Sistem Produksi Padi Berkelanjutan dengan Penerapan Revolusi Hijau Lestari. Iptek Tanaman Pangan No. $1: 1-18$

[3] Eliazer Nelson, A.R.L., Ravichandran, K. \& Antony, $\mathrm{U}$. The impact of the Green Revolution on indigenous crops of India. J. Ethn. Food 6, 8 (2019) doi:10.1186/s42779-019-0011-9

[4] Pranaji, T., Saptana, dan W. K. Sejati, 2005. Pengelolaan Serangga dan Pertanian Organik Berkelanjutan di Pedesaan. Forum Penelitian Agroekonomi, Vol. 23 (1) : 38-47. Puslitbang Sosek Pertanian, Bogor.

[5] Siwi, B.H. dan S. Kartowinoto. 1989. Plasma Nutfah Padi dalam Padi Buku 2. Badan Penelitian dan Pengembangan pertanian, Pusat Penelitian dan Pengembangan Tanaman Pangan. Bogor.

[6] Joseph, S. 2002. Management of Diversity of Local Rice and Organic Agriculture for Strengthening Indonesia's Food Security. Centre of Study and Development of Indonesian Rice (Pusspaindo). Paper presented to the GRAIN International Workshop on the Local Management of Agricultural Biodiversity, Rio Branco, Brazil, 9-19 May 2002.

[7] Anhar, A. 1996. Kelestarian Plasma Nutfah Padi Lokal Pasca intensifikasi (Studi Kasus di Kabupaten Solok, Sumatera Barat). Disertasi. Program Pascasarjana . Universitas Indonesia.

[8] Savci, S. 2012. An Agricultural Pollutant: Chemical Fertilizer. International Journal of Environmental Science and Development, Vol. 3, No. 1:73-80

[9] Nursinah, I. Z., \& Taryadi, T. 2009. Penerapan SRI (System of Rice Intensification) Sebagai Alternatif
Budidaya Padi Organik. CEFARS: Jurnal Agribisnis dan Pengembangan Wilayah, 1(1), 30-43

[10] Mayrowani, H. 2012.Pengembangan Pertanian Organik Di Indonesia. FORUM PENELITIAN AGRO EKONOMI,Volume 30 No.2: 91-108

[11] Ristianingrum, Anita; M. A. Chozin,; Machfud; Sugiyanta dan Mulatsih, Sri. 2016. Optimalisasi Keberlanjutan Pengembangan Usaha Padi Organik di Kabupaten Cianjur, Jawa Barat. Jurnal Manajemen \& Agribisnis, Vol. 13 No. 1.

[12] Nurnayetti dan Atman. 2013. Keunggulan Kompetitif Padi Sawah Varietas Lokal di Sumatera Barat. Jurnal Pengkajian dan Pengembangan Teknologi Pertanian. Vol. 16, No.2, Agustus 2013: 100-108

[13] Kurniadiningsih, Yanti, dan Sri Legowo. 2012. Evaluasi untung rugi penerapan metode SRI (system of rice intensification) di Cihea Kabupaten Cianjur Jawa Barat. Wartazoa Vol 18 No. 7, 97-105.

[14] Sudiarti, D. (2017). The Effectiveness of Biofertilizer on Plant Growth Soybean "EDAMAM E”(Glycine Max). Jurnal Sain Health, 1(2), 46-55

[15] Bhattacharjee, R and U.Dey. 2014.Biofertilizer, a way towards organic agriculture: A review. Afr. J. Microbiol. Res. Vol 8(24):2332-2342. http://ww. Academic journals. org/AMJR

[16] Hajieghrari, B and M. Mohammadi. 2016. Growthpromoting activity of indigenous Trichoderma isolates on wheat seed germination, seedling growth and yield. AJCS 10(9):1339-1347 . DOI: 10.21475/ajcs.2016.10.09.p7857

[17] Syamsiah, M. 2017. Pengujian Perlakuan Trichoderma spp. Pada Media Tanam Terhadap Vigor Benih Padi Pandan wangi Cianjur. AGROSCIENCE, 7(2):266-280

[18] Abri, T., Kuswinanti., E. L. Sengin, and R. Sjahrir. 2015. Isolasi Cendawan Rhizosfer Penghasil Hormon Indol Acetic Acid (IAA) pada Padi Aromatik Tanatoraja. Prosidding Seminar Nasional Mikrobiologi Kesehatan dan Lingkungan. ISBN: 978-602-72245-0-6.

[19] Doni, F., N.K.N. Al-Shorgani, E.M.M. Tibin, N.N. Abuelhassan, I. Anizan, C.M.Z. Che Radziah and W.Y. Wan Mohtar, 2013. Microbial involvement in growth of paddy. Curr. Res. J. Biol. Sci., 5(6): 285-290.

[20] Masunaka, A., M. Hyakumachi, and S. Takenaka. 2011. Plant Growth-Promoting Fungus, Trichoderma 
Koningi Suppresses Isoflavonoid Phytoalexin Vestitol Production For Colonization On/In The Roots Of Lotus japonicus. Microbes Environ. 26(2) 128-134

[21] Rajjou, L., M. Duval, K. Gallardo, J. Catusse, J. Bally, C. Job and D. Job, 2012. Seed germination and vigor.Ann.Rev.Plant.Biol.,63:507-533

[22] Doni, F., Isahak, A., Che Mohd Zain, C.R. et al. Physiological and growth response of rice plants (Oryza sativa L.) to Trichoderma spp. inoculants. AMB Expr 4, 45 (2014) doi:10.1186/s13568-0140045-8

[23] Sartika, I. D. 2017. Respon Pertumbuhan Benih Padi Gogo Situ Bagendit (Oryza sativa L.) Terhadap Beberapa Asal Isolat Trichoderma spp. FMIPA UNP. Padang.

[24] Anhar, A., L Advinda, Irdawati and M H Syahputra . 2018. Germination responses of local lowland rice variety Sirandah Kuning to application of some Trichoderma strain. J. Phys.: Conf. Ser.1116 052006

[25] Khadka, R. B., \& Uphoff, N. (2019). Effects of Trichoderma seedling treatment with System of Rice Intensification management and with conventional management of transplanted rice. PeerJ, 7, e5877. doi: $10.7717 /$ peerj.5877

[26] Hatta, M. 2012. Uji Jarak Tanam Sistem Legowo terhadap Pertumbuhan dan Hasil Beberapa Varietas Padi pada Metode SRI. Jurnal Agrista, Vol. 16 No.2 :87-93

[27] Zhang Y, Yu C, Lin J, Liu J, Liu B, Wang J. 2017. Regulates plant height and improves grain yield in rice. PLoS ONE 12(7): e0180825. https://doi.org/10.1371/journal. pone. 0180825

[28] Nazirah, L. and B.S.J. Damanik. 2015. Pertumbuhan dan hasil tiga varietas padi gogo pada perlakuan pemupukan. Jurnal Floratek. 10:54-60

[29] Kadidaa, B., G Sadimantara., S La Ode, Safuan and Muhidin.2017. Genetic Diversity of Local Upland Rice (Oryza sativa L.) Genotypes Based on Agronomic Traits and Yield Potential in North Buton, Indonesia. Asean J.Crop. Sci. 9(4):109-1017

[30] Luo, A., Qian Qian, Hengfu Yin, Xiaoqiang Liu, Changxi Yin, Ying Lan, Jiuyou Tang, Zuoshun Tang, Shouyun Cao, Xiujie Wang, Kai Xia, Xiangdong Fu, Da Luo, Chengcai Chu, 2006. EUI1, Encoding a Putative Cytochrome P450 Monooxygenase, Regulates Internode Elongation by Modulating Gibberellin Responses in Rice, Plant and Cell Physiology, Volume 47, Issue 2, February 2006, Pages 181-191,

https://doi.org/10.1093/pcp/pci233

[31] Ishimaru, Ken \& Ono, Kiyomi \& Kashiwagi, Takayuki. 2004. Identification of a new gene controlling plant height in rice using the candidategene trategy. Planta. 218. 388-95. 10.1007/s00425003-1119-z.

[32] Xie, Y., Yaling Zhang, Jingluan Han, Jikai Luo, Gousi Li, Jianle Huang, Haibin Wu, Qingwei Tian, Qinlong Zhu, Yuanling Chen, Yoji Kawano, YaoGuang Liu and Letian Chen. 2018. The Intronic cis Element SE1 Recruits trans-Acting Repressor Complexes to Repress the Expression of ELONGATED of UPPERMOST INTERNODE1 in Rice. Molecular Plant 11, 720-735, May 2018

[33] Sitohang, F R H., L A M Siregar and L A P. Putri. 2014. Evaluasi pertumbuhan dan produksi beberapa varietas padi gogo (oryza sativa 1.) Pada beberapa jarak tanam yang berbeda. Jurnal Online Agroekoteknologi . Vol.2, No.2 : 661 - 679, ISSN No. 2337- 6597 .

[34] Sitinja, H and Idwar. 2015. Respons of paddy rice (oryza sativa 1.) Varieties that planted with cultivation approachment of jajar legowo and tegel system. JOM Faperta Vol. 2 No.2:

[35] Suryanugraha W A, Supriyanta and Kristamtini. 2017. The Performance of Ten Local Rice (Oryza sativa L.) Cultivars of Yogyakarta Special Territory. Vegetalika. 6(4): 55-70

[36] López-Cristoffanini, C.,. Xavier Serrat, Olga Jáuregui, Salvador Nogués and Marta LópezCarbonell. 2019.Phytohormone Profiling Method for Rice: Effects of GA20ox Mutation on the Gibberellin Content of Japonica Rice Varieties. Front. Plant Sci. 10:733 doi: $10.3389 /$ fpls.2019.00733

[37] Yang, X., Hwa, C. Genetic modification of plant architecture and variety improvement in rice. 2008. Heredity 101, 396-404 doi:10.1038/hdy.2008.90

[38] Vinale, F., Sivasithamparam, K., Ghisalberti, E., Ruocco, M., Woo, S., \& Lorito, M. 2012. Trichoderma Secondary Metabolites that Affect Plant Metabolism. Natural Product Communications, 7(11), 1545- 1550.

[39] Cai F, Yu G, Wang P, Wei Z, Fu L, Shen Q, Chen W. Harzianolide, a novel plant growth regulator and systemic resistance elicitor from Trichoderma harzianum. 2013. Plant Physiol Biochem.;4:106113. doi: 10.1016/j.plaphy.2013.08.011 
[40] Saldajeno, M.G.B., Naznin, H.A., Elsharkawy, M.M., Shimizu, M. \& Hyakumachi, M. 2014.

Enhanced resistance of plants to disease using Trichoderma spp. Biotechnology and Biology of Trichoderma: 477-487.

[41] Hoyos-Carvajal L, Orduz S, Bissett J. 2009). Growth stimulation in bean (Phaseolus vulgaris L.) by Trichoderma. Biological Control, 51, 409-416.

[42] Stewart, A and Robert Hill,.2014. Applications of Trichoderma in Plant Growth Promotion in Biotechnology and Biology of Trichoderma. 415428.

[43] Yuvraj, 2017. Rhizosfere Competence, Plant Growth Promoting Activities and Disease Controlling Potential of Trichoderma spp. Thesis. Department Of Plant Pathology College Of Agriculture, Raipur Faculty Agriculture. Indira Gandhi Krishi Vishwavidyalaya, Raipur (Chhattisgarh).

[44] Martínez-Medina, A., Maria Del Mar Alguacil Jose A. Pascual Saskia C.M. Van Wees. 2014. Phytohormone Profiles Induced by Trichoderma Isolates Correspond with Their Biocontrol and Plant Growth-Promoting Activity on Melon Plants. J.Chem Ecol (2014) 40:804-815. 